\title{
The Effect of Motivation and Communication on Student Competence in Microeconomics
}

\author{
Wily Julitawaty \\ \{wilyjulitawaty@yahoo.com\} \\ STIE Professional Management College Indonesia
}

\begin{abstract}
In the learning process, one of the things needed is motivation to learn. This motivation is a person's effort to achieve good results. Motivation to learn needs to encourage to achieve maximum performance or results. The need for learning motivation to support every learning activity. Furthermore, what is needed in the learning process is good communication. Communication is the delivery of the intent and purpose to share information directly or indirectly or through the media. Communication also functions to solve problems in a group or organizational environment. This communication is needed in every face-to-face learning. Decent competence is a competence that is the result of one's creativity and innovation. Competence is a person's ability to develop. Competence is needed in the field of education and one's life experience. In the learning process, this competency value has a sale value. Data analysis techniques using multiple linear regression. The results partially showed that motivation does not affect competence, while communication has significant effect on competence. The results simultaneously showed that motivation and communication significantly influence competence.
\end{abstract}

Keywords: Motivation, Communication, Competence

\section{Introduction}

Higher education is a level of education after secondary education which includes diploma, bachelor, master, specialist, and doctoral education programs organized by higher education. Higher education is held in an open system. Higher education can take the form of colleges, high school polytechnics, institutes, or universities. Higher education institutions are obliged to organize education, research and community service. Higher education can hold academic, professional, and/or vocational (professional vocational) programs. [4]

The term learning is the development of the term teaching. In simple learning is an effort made by an educator to learn students who learn. Informal education (schools), learning is a task that is charged to educators, because educators are professionals who are prepared to teach. [2]

In the learning process, one of the things needed is motivation to learn. This motivation is a person's effort to achieve good results. Motivation to learn needs to encourage to achieve maximum performance or results. The need for learning motivation to support every learning activity.

Furthermore, what is needed in the learning process is good communication. Communication is the delivery of the intent and purpose to share information directly or indirectly or through the media. Communication also functions to solve problems in a group or organizational environment. This communication is needed in every face-to-face learning. 
Decent competence is a competence that is the result of one's creativity and innovation. Competence is a person's ability to develop. Competence is needed in the field of education and one's life experience. In the learning process, this competency value has a sale value.

\section{Literature Review}

Motivation is a behavioral activity that works to meet the desired needs. Each individual has a motivation that can become a spirit in referring and fostering work spirit in work. Sprit owned by a person can be sourced from himself or from outside, where both forms will be better if both of them come together to be a motivator for someone. [7]

Motivation that works in individuals has different strengths. Some motives are so strong that they master other motives. The most powerful motive is the motive to be the main cause of individual behavior at a particular moment. While weak motives have almost no influence on individual behavior. Strong motives at the time will become very weak because there are stronger motives at the time. [5]

The indicators of learning motivation according to Sardiman (2004:81) are as follows: 1) Persevering in task 2) Resilient in facing difficulties (not quickly despairing), 3) Showing interest in various problems adults, 4) Prefer to work independently, 5) Get bored easily with routine tasks, and 6) Can defend their opinions rationally. If someone already has the characteristics as mentioned above, it means that someone already has a high motivation to learn. Having learning motivation following these characteristics becomes very necessary in learning activities if you want to succeed well. Learning activities carried out by students seriously, diligently, tenaciously, and attached to doing and completing assignments can help students solve various problems and obstacles independently, students who learn well will not get caught up in something that happens continuously. [5]

Communication is the process of delivering messages or intentions carried out through one party or person to another party or person whether done directly or through the media. [8] Group communication is a face-to-face interaction between three or more people, with known goals, such as sharing information, protecting yourself, solving problems, where members can remember the personal characteristics of other members appropriately. Whereas organizational communication is the sending and receiving of various organizational messages in formal and informal groups from an organization. [9]

There are two indicators most often used to classify communication-based on the context, namely the number of participants involved in communication and the level or level of communication. Based on the number of participants involved in communication, several terms are known including interpersonal communication, dyadic communication, interpersonal communication, small group communication, public communication, organizational communication, and mass communication. As for when viewed from the level or level of communication, communication can be broken down into four levels, namely interpersonal communication, group communication, organizational communication, and mass communication. [1]

Competence is an ability possessed by an individual who has a sale value and is applied from the results of creativity and innovation produced. In the world of work the higher one's competence, the higher the person's selling value, meaning that the financial gain that can be obtained will be higher. To get the value of competence, he was asked to do self-development both in terms of education and experience which all of this is often called learning. [8] 
General competence: students can express thoughts and ideas effectively and efficiently and are communicative in scientific writing, reports, letters, proposals, and can speak verbally spontaneously or in a planned manner. Special competencies: students with adequate knowledge; ..., applying the process of writing scientific papers, articles, reports, proposals, official letters, applying the steps of scientific presentations effectively and attractively informal situations; and skilled at presenting scientific presentations with multimedia, (Syiahbuddin, 2006:2-3). [6]

Likert Scale is used to measure the attitudes, opinions, and perceptions of a person or group of people about social phenomena. In research, this social phenomenon has been specifically determined by the researcher, hereinafter referred to as the research variable. With a Likert scale, the variables to be measured are translated into indicator variables. Then the indicator is used as a starting point for arranging instrument items which can be statements or questions. [3]

For quantitative analysis, answers can be given a score, for example:

1. Agree/always/very positive given a score of 5

2. Agree/often/positively given a score of 4

3. Hesitated/sometimes/neutral given a score of 3

4. Disagree/rarely/negatively given a score of 2

5. Strongly disagree/never given a score of 1

\section{Methods}

The study was conducted at STIE PMCI Medan in 2019. The study was conducted using a Questionnaire and a Likert scale. Samples taken were 60 students and 17 statements. Data Analysis Techniques in this study used Multiple Linear Regression. The results are processed using Eviews 9.0.

\section{Result \& Discussion}

The results of processing using Eviews 9.0 are shown in the table below:

Dependent Variable: Y

Method: Least Squares

Date: 11/09/19 Time: 18:16

Sample: 160

Included observations: 60

\begin{tabular}{lrlll}
\hline \hline \multicolumn{1}{c}{ Variable } & Coefficien & & \\
t & Std. Error & t-Statistic & Prob. \\
\hline \hline \multicolumn{1}{c}{ X1 } & 0.115488 & 0.143174 & 0.806628 & 0.4232 \\
X2 & 0.314510 & 0.133430 & 2.357126 & 0.0219 \\
C & 6.778736 & 3.468208 & 1.954535 & 0.0555 \\
\hline \hline R-squared & 0.130838 & Mean dependent var & 16.28333 \\
Adjusted R-squared & 0.100342 & S.D. dependent var & 2.693946 \\
S.E. of regression & 2.555216 & Akaike info criterion & 4.762858 \\
Sum squared resid & 372.1605 & Schwarz criterion & 4.867575 \\
& \multicolumn{4}{c}{ Hannan-Quinn } \\
Log likelihood & -139.8857 criter. & \\
F-statistic & 4.290224 & Durbin-Watson stat & 1.953806
\end{tabular}


$\operatorname{Prob}(\mathrm{F}$-statistic) $\quad 0.018381$

Table 1. Results of Multiple Linear Regression Analysis

From the table above, we get the linear regression equation namely:

$$
\mathrm{Y}=6,778736+0,115488 \mathrm{X} 1+0,314510 \mathrm{X} 2+\mathrm{e}
$$

Adjusted R-squared value of 0.100342 can be known as $10.03 \%$ can be explained by the Motivation and Communication variables of Competence. The remaining $89.97 \%$ is influenced by variables not examined in this model.

Result of t-test show that:

- In the Motivation of Competence variable, $t_{\text {count }}=0.806628$ is smaller than $t_{\text {table }}=$ 2.00172 and $t_{\text {statistic }}$ significant value $=0.4232$ is greater than 0.05 ; it can be seen that Motivation has no effect on Competence.

- In the Communication variable on Competence, it is obtained that $t_{\text {count }}=2.357126$ is greater than $t_{\text {table }}=2.00172$ and the significant value of $t_{\text {statistic }}=0.0219$ is less than 0.05 ; can be seen that communication has a significant effect on competence.

Result of F-test show that:

- In the Motivation and Communication variable of Competence, $F_{\text {count }}=4.290224$ is greater than 3.16 and the significant value Prob $\left(\mathrm{F}_{\text {statistic }}\right)=0.018381$ is less than 0.05 ; it can be seen that Motivation and Communication have a significant effect on Competence.

\section{Conclusion}

- The research results partially showed that motivation does not affect competence.

- The research results partially showed that communication has significant effect on competence.

- The research results simultaneously showed that motivation and communication have significant influenced competence.

\section{Suggestion}

- Students need to learn how to motivate themselves, communicate with others so that competence is obtained for each subject they study.

- The existence of a two-way learning process in every existing learning.

\section{Reference}

[1] Nofrion, "Komunikasi Pendidikan Penerapan Teori dan Konsep Komunikasi dalam Pembelajaran,” Jakarta: Kencana, 2016, pp. 20-22.

[2] D. Rosdiani, "Manajemen Pendidikan," Bandung: Alfabeta, 2018, p. 106.

[3] Sugiyono, "Metode Penelitian Pendidikan (Pendekatan Kuantitatif, Kualitatif, Dan R\&D)," Bandung: Alfabeta, 2018, pp. 134-135.

[4] O. Supriadi, "Pengantar Manajemen Pendidikan," Yogyakarta: LaksBang PRESSindo, 2018, p. 14. 
[5] A. Susanto, "Bimbingan Dan Konseling Di Sekolah: Konsep, Teori, dan Aplikasinya," Jakarta: Prenadamedia Group, 2018, pp. 45-46.

[6] Widjono, "Bahasa Indonesia: Mata Kuliah Pengembangan Kepribadian di Perguruan Tinggi,” Jakarta: Grasindo, 2017, p. 8.

[7] I. Fahmi, "Manajemen Kepemimpinan: Teori \& Aplikasi," Bandung: Alfabeta, 2013, p. 190.

[8] I. Fahmi, "Perilaku Organisasi: Teori, Aplikasi, Dan Kasus," Bandung: Alfabeta, 2016, pp. 40, 163.

[9] A. Subkhi and M. Jauhar, "Pengantar Teori \& Perilaku Organisasi," Jakarta: Prestasi Pustaka, 2013, p. 292. 